\title{
O CONSUMO DE NOTÍCIAS POR AGRICULTORES: A MÍDIA NAS ATIVIDADES DIÁRIAS
}

\author{
THE NEWS CONSUMPTION BY FARMERS: THE MEDIA IN DAILY \\ ACTIVITIES \\ CONSUMO DE NOTICIAS POR AGRICULTORES: LOS MEDIOS DE \\ COMUNICACIÓN EN LAS ACTIVIDADES DIARIAS
}

Lirian Sifuentes dos Santos
PUCRS
lisifuentes@yahoo.com.br
Keli Camiloti
Unochapecó

\section{Resumo}

O presente artigo tem como objetivo compreender o consumo de notícias por agricultores de São Domingos, região oeste de Santa Catarina. Buscamos entender, por meio de um estudo de caso, a relação existente entre os agricultores e a mídia, e de que forma as notícias que eles consomem interferem em suas atividades do dia a dia. Para isso, num primeiro momento, foram aplicados questionários a um grupo de 18 agricultores. Depois, foram selecionados seis desses, que participaram de uma entrevista. Entre os resultados, ressaltamos o destaque que é dado pelos mesmos aos meios de comunicação em seu cotidiano, admitindo, inclusive, ser a mídia uma aliada e companheira para o trabalho agrícola.

Palavras-chave: Consumo midiático; notícias; agricultores.

\begin{abstract}
This article aims to understand the news consumption by farmers in São Domingos, west of Santa Catarina. We try to understand, by a case study, the relationship between farmers and the media, and how the news they consume interfere in their day to day activities. For this, at first, questionnaires were administered to a group of 18 farmers. Then, we selected six of those who participated in an interview. Among the results, we note the emphasis given by them to the media in their daily lives, admitting even be the media partner and an ally for agricultural work.
\end{abstract}

Keywords: Media consumption, news; farmers. 


\section{Resumen}

Este artículo tiene como objetivo comprender el consumo de noticias por los agricultores en São Domingos, al oeste de Santa Catarina. Tratamos de entender, por un estudio de caso, la relación entre los agricultores y los medios de comunicación, y cómo las noticias que consumen interferir en sus actividades del día a día. Para ello, en primer lugar, se administraron cuestionarios a un grupo de 18 agricultores. A continuación, se seleccionaron seis de los que participaron en una entrevista. Entre los resultados, se observa el énfasis dado por ellos a los medios de comunicación en su vida cotidiana, admitiendo incluso ser el socio de medios y un aliado para el trabajo agrícola.

Palabras clave: Consumo de medios de comunicación; noticias; agricultores.

\section{Introdução}

Nas comunidades rurais, os meios de comunicação são de fundamental importância, uma vez que são uma importante ferramenta de informação. Dessa forma, o jornalismo rural tem se desenvolvido, e a agricultura vêm ganhando grande destaque na mídia nos últimos tempos. E isso se deve a acontecimentos históricos, que demonstram a importância desse setor para o nosso país.

Nesse contexto, o presente artigo procura, por meio de um estudo de caso, compreender como é o consumo das notícias ${ }^{1}$ veiculadas pela mídia pelos agricultores que residem na zona rural do município de São Domingos-SC. Para isso, é importante entender a relação entre os agricultores e a mídia, analisar como ela está presente no cotidiano dos agricultores, além de verificar como eles utilizam as mídias em seu dia-a-dia e de que forma as notícias interferem nas suas atividades rotineiras. Dessa forma, foi realizado um estudo de consumo com seis agricultores selecionados a partir do questionário, em entrevistas informais realizadas nas casas dos mesmos.

\footnotetext{
${ }^{1}$ É importante destacar que este trabalho não se propõe a fazer um estudo de recepção tradicional, e sim um estudo de consumo midiático, conforme já diferenciado por outros autores, como Sifuentes (2012) e Jacks e Escosteguy (2005). A distinção entre as abordagens pode ser assim resumida: "a recepção, surgida primeiro, tem como propósito a compreensão de um momento específico na interação com a mídia, a partir de um texto motivador da investigação. Em seu desenvolvimento, posteriormente, essa relação passou a ser menos direta, sendo suficiente o interesse por um contexto, constituindo os estudos de consumo" (SIFUENTES, 2012, p. 5). O aporte teórico e metodológico, no entanto, são bastante semelhantes, visto que estudam a audiência e partem dos estudos culturais. Assim, e pensando que os estudos de recepção possuem mais bagagem teórica, faremos uso das referências sobre os mesmos.
} 
O motivo de escolher o meio rural como alvo da pesquisa foi devido a importância que o campo tem em nosso país e, principalmente, em nossa região. A agricultura continua sendo a atividade principal de ocupação e renda de parte significativa da população de Santa Catarina, embora minoritária ${ }^{2}$. Esse é um dos motivos que torna indispensável que se desenvolvam pesquisas sobre os moradores do campo em nosso país, valorizando sua cultura e compreendendo sua realidade.

O município de São Domingos foi escolhido por ser caracterizado como essencialmente agrícola, contando com propriedades que representam grande parte do movimento econômico local. São Domingos está localizado a cerca de 600 quilômetros da capital do estado de Santa Catarina, Florianópolis, e é um município de pequeno porte, com pouco mais de nove mil habitantes, sendo que $43,1 \%$ da sua população vive na zona rural.

\section{Estudos culturais e recepção: pesquisando a audiência}

Gomes (2004, p. 103) afirma que os estudos culturais ingleses surgiram a partir da preocupação em compreender como são as práticas e as instituições culturais e a relação com a sociedade e as transformações sociais. Com isso, o foco é entender como os meios de comunicação conseguem se inserir no tecido cultural contemporâneo. "Os objetos que circulam entre os sujeitos humanos [como a mídia] são entidades construídas no âmbito da prática cultural e só neste âmbito adquirem seu valor".

Os estudos culturais tracejam a forma como as produções culturais articulam ideologias, valores, classes, entre outros fatores, na sociedade, e o modo como eles se interrelacionam (KELLNER, 2001). Tudo isso ainda está voltado à construção de identidades e questões de classe e ideologia, ligadas ao enfoque de seus fundadores.

Além disso, Kellner (2001) acredita que os estudos culturais consideram que cada receptor interpreta as mensagens de forma diferente, da mesma forma que cada jornalista, por exemplo, cria um novo significado, produzido a partir de sua interpretação, transmitido aos receptores. Mesmo assim, o poder do emissor é grande, já que a mensagem transmitida por

\footnotetext{
${ }^{2}$ De acordo com o Censo 2010 (IBGE, 2011), a população rural de Santa Catarina é de 1.000.534, representando $16 \%$ do número total de moradores do estado.
} 
ele afeta o que o receptor recebe, porque sofreu a influência do que é sentido pelo emissor que o produz.

Dessa forma, Jacks e Escosteguy (2005) afirmam, de modo resumido, que os estudos culturais se interessam pelas relações entre textos, grupos sociais e contextos, bem como pelas práticas simbólicas e as estruturas de poder. Então, a partir daí, os estudos foram definidos como interessados em um processo global de produção de sentido, que substitui o entendimento de uma visão monopolizada, valorizando a cultura popular como um "discurso social relevante".

Os estudos de recepção podem ser considerados como um importante desenvolvimento dos estudos culturais. Para Jacks e Escosteguy (2005), a recepção apropriase das balizas dos estudos culturais para a pesquisa empírica acerca dos significados que a mensagem dos meios transmite, considerando-a como formas culturais abertas a diferentes decodificações. A audiência, para os estudos de recepção, é composta de agentes que produzem o sentido.

Gobbi (2011, p.10) explica que "estudar a recepção midiática implica necessariamente uma preocupação com a maneira como o receptor se apropria das mensagens emitidas pelos meios de comunicação". Para Corner (apud GOMES, 2004, p. 175), os estudos de recepção são entendidos como

Um tipo particular de pesquisa de audiência, distintivo pelo montante de interesse que mostram pelas questões que têm a ver com a organização simbólica e discursiva da produção dos media e aqueles processos de produção de sentido através dos quais compreensão, significação e prazer são gerados.

Estudar recepção não é simplesmente checar se a audiência dos meios de comunicação alcança os sentidos que querem transmitir aos emissores. Jacks e Escosteguy (2005) afirmam que a recepção deve procurar os diferentes sentidos construídos pela audiência, a partir das mensagens disponibilizadas pelos media. Além disso, a diversidade de sentidos também pode ser analisada como uma atividade dos receptores.

Para tanto, o melhor lugar para analisar o processo de recepção é o cotidiano, pois é nele que o indivíduo demonstra seu verdadeiro "eu". Além disso, eles creem que a recepção é um fenômeno coletivo, que também inclui conflitos, diferenças e semelhanças entre o moderno e o tradicional. Assim, Grohmann ainda afirma que a pesquisa de recepção se 
envolve no cotidiano das pessoas, e começa bem antes do fato de receber uma mensagem, bem como termina bem depois dessa recepção, criando, assim, um círculo de interação.

O conceito de mediações possui uma grande importância quando se fala no debate sobre recepção midiática, tendo como uma referência na área, Jesús Martín-Barbero. Jacks (1996, p. 47) cita que o conceito de mediações é caracterizado por "um conjunto de influências que estrutura, organiza e reorganiza a percepção da realidade em que está inserido o receptor, tendo poder também para valorizar implícita ou explicitamente esta realidade".

O indivíduo está exposto a diversas mediações, e todas elas podem se manifestar por meio do seu discurso e das ações que interferem explicitamente no modo como cada membro da audiência interpreta o discurso dos meios de comunicação. Gobbi (2011) acrescenta que mesmo que haja uma intenção, seja ela de forma implícita ou explícita, na mensagem que foi emitida, o sentido continua sendo dado pelo receptor, que se baseia em sua cultura, referências e experiência de vida para interpretá-la.

A principal mediação utilizada nesta pesquisa é a mediação da cultura rural. Ronsini (2004, p. 72) afirma que o lugar onde a pessoa vive é fundamental para caracterizar seu comportamento, bem como é uma referência para compreender o papel dos meios de comunicação na vida das pessoas. "As características do lugar determinam um estilo de vida, um modo de andar, de comer, de se divertir, de conviver com os amigos e familiares, etc.".

Desse modo, o pesquisador também deve buscar compreender como se dá a relação da pessoa com o meio em que vive, e, em nosso caso, ao realizar um estudo de recepção, pensar a relação entre essas pessoas - agricultores - e os meios de comunicação, protagonistas na sociedade atual.

\section{O meio rural e seu desenvolvimento contemporâneo}

Na avaliação de Lefebvre (1975), a distinção entre o campo e a cidade toma lugar entre as pioneiras e essenciais divisões do trabalho. Corresponde à separação entre o trabalho material e o trabalho intelectual, pois à cidade cabe funções de organização, direção, atividades políticas, militares e elaboração do conhecimento. 
Williams (1989) expõe que as oposições entre o rural e o urbano vêm sendo construídas ao longo dos séculos. O autor mostra que a origem da distinção é antiga, tendo se tornado mais significativa com o capitalismo.

\begin{abstract}
A divisão e oposição entre cidade e campo, indústria e agricultura, em suas formas modernas, representa a culminação crítica do processo de divisão e especialização do trabalho que, embora não tivesse início com o capitalismo, foi desenvolvido dentro do capitalismo a um grau extraordinário e transformador. Esta divisão fundamental se manifesta sob outras formas: a separação entre trabalho mental e trabalho braçal, entre administração e execução, entre política e vida social (WILLIAMS, 1989, p. 407).
\end{abstract}

$\mathrm{Na}$ história humana, campo e cidade passaram a significar ideias antagônicas. De um lado, o campo é associado à vida simples, tranquila, harmoniosa e inocente. À cidade, por sua vez, foram atribuídos valores referentes ao saber, à comunicação e à luz. Ambos, porém, também possuem características negativas associadas a eles. A ignorância, a limitação e a pobreza ligam-se ao campo, enquanto o barulho, os prazeres mundanos e a competição são atrelados à cidade (WILLIANS, 1989).

A separação entre campo e cidade ainda gera controvérsias no Brasil. A análise desenvolvida por José Eli Veiga, em "Cidades imaginárias: o Brasil é menos urbano do que calcula" (2003), tem sido motivo de debate sobre o que propriamente caracteriza uma cidade no Brasil. O autor indaga se em pleno século 21 podemos considerar "cidade" um aglomerado de menos de 20 mil pessoas (VEIGA, 2003). Veiga salienta que a definição de cidade em vigor no país foi estabelecida através do Decreto-Lei 311, de 1938, que transformou em cidade todas as sedes municipais da época.

Caso o Brasil empregasse o parâmetro utilizado pela OCDE (Organização para a Cooperação e o Desenvolvimento Econômico), que classifica como urbana a localidade que apresenta densidade demográfica superior a 150 habitantes $/ \mathrm{km}^{2}$, somente 411 , dos 5.507 municípios brasileiros, em 2000, seriam considerados urbanos (VEIGA, 2003). A partir desse critério, apenas $57 \%$ da população brasileira viveria em área urbana, número bastante inferior aos $81,2 \%$ de brasileiros que hoje habitam nas cidades.

Para Sobarzo, reflexões que visem uma classificação estatística e que tenham como resultado o tamanho do Brasil urbano e rural, especialmente como faz Veiga, não são pertinentes. $\mathrm{O}$ autor argumenta que "nesse quadro de redefinição das relações cidade/campo, uma diferenciação estatística entre urbano e rural perde importância porque fica restrita ao 
plano da forma e não dá conta da dinâmica e dos processos presentes no plano do conteúdo" (SOBARZO, 2006, p. 56).

É difícil, contudo, encontrar uma definição para o rural, que vai ganhando novos significados à medida que aumentam o número de pesquisas na área. Para Aldo Solari (1979 apud SIQUEIRA; OSÓRIO, 2001, p. 73) “(...) o rural se caracteriza por um determinado tipo de atividade: a produção de alimentos através da criação de plantas e animais". Junto a isso está o fato de que o morador da zona rural está em constante contato com a natureza e muitas vezes também não dispõe de todas as facilidades encontradas nos centros urbanos. No entanto, como destaca Wanderley, o camponês não está isolado ao restante da sociedade brasileira.

Quando estou falando de mundo rural, refiro-me a um universo socialmente integrado ao conjunto da sociedade brasileira e ao contexto atual das relações internacionais. Não estou, portanto, supondo a existência de um qualquer universo isolado, autônomo em relação ao conjunto da sociedade e que tenha lógicas exclusivas de funcionamento e reprodução. Porém, considero que este mundo rural mantém particularidades históricas, sociais, culturais e ecológicas, que o recortam como uma realidade própria, da qual fazem parte, inclusive, as próprias formas de inserção na sociedade que o engloba. (WANDERLEY, 1997, p. 3)

Pérez (2001) ainda define o meio rural como um conjunto de regiões em que a população desenvolve várias atividades em diversos setores, como agricultura, artesanato, implementação de pequenas e médias indústrias rurais, extração de recursos minerais, naturais e turismo, entre outros. Através disso, o campo mantém contato com os centros urbanos e vai modificando mais uma vez suas características.

Por isso o autor também concorda que os conceitos de rural foram modificados à medida que estudos revelaram com mais clareza e complexidade as realidades que envolvem o meio rural, bem como suas limitações e possibilidades de expansão. Enquanto isso, os conceitos foram se aperfeiçoando e tomando novas dimensões, a partir de um modelo de desenvolvimento global que surgia.

Teubal (2001) acredita que muitos fenômenos que se manifestam atualmente, tanto no meio rural quanto urbano, podem ser relacionados como resultado do processo de globalização, que está presente na vida de toda população. Entre as formas de manifestação desse fenômeno, destaca-se a concentração de terras, a mecanização da agricultura e também 
as novas possibilidades que surgiram através das exportações dos produtos oriundos da agricultura.

O desenvolvimento e a chegada das novas tecnologias ao meio rural foram modificando o perfil das famílias agricultoras. Pensando nisso, Pérez (2001) concorda que

Por su parte, las sociedades rurales han presentado cambios estructurales, debidos en buena parte al modelo de desarrollo global. Estos cambios hacen que tengamos que ver y analizar lo rural de distinta forma y, en esta medida, que las definiciones y estrategias del desarrollo rural se adapten a dichas modificaciones.

Com a chegada da globalização e das novas tecnologias, aliados a um acesso maior à educação e a mudança de perfil das famílias, o êxodo rural foi ganhando força, pois as novas gerações não querem ou não conseguem mais viver na zona rural. Um fator que dificulta a permanência dos jovens no campo é o tipo de trabalho. Dados da pesquisa de Pozenato e Giron (2007) mostram que, mesmo com a chegada de uma agricultura mecanizada, o trabalho não cessa. O que acontece é a variação do trabalho, um pouco menos cansativo quem sabe, mas continua nos 365 dias do ano, faça chuva ou faça sol, independente de estação.

Os agricultores foram se interessando pelas novas tecnologias e passaram a acompanhar as novidades que surgiam. Esse desenvolvimento se deu também graças aos grupos em que passaram a participar e da sua organização como forma de compartilhar suas experiências em cada contexto e propriedade.

Gradualmente, o nível de consciência dos produtores foi crescendo, organizaram-se em sindicatos e cooperativas, e passaram a exigir mais diálogo e menos propaganda. A informação rural, baseada não mais na difusão unilateral de informação e instruções, mas no diálogo entre os diversos setores que compõe o setor agrícola [...]. Deste macrodiálogo surgem não somente melhores condições para a transferência tecnológica (que é o que a informação rural almejava), mas para resolver qualquer problema técnico, econômico ou político que afete o bem-estar da população rural (e inclusive da população urbana que consome seus produtos). (BORDENAVE, 2003, p.79)

Atualmente, o campo também é visto como portador de soluções. Isso se deve ao fato de que as pessoas começaram a perceber que o meio rural pode despertar alternativas para o problema de emprego. Além disso, a qualidade de vida do campo costuma ser superior a dos centros urbanos, já que o contato com a natureza é direto e intenso. 
Quando os veículos de comunicação perceberam a importância e o significado da agricultura para o movimento econômico, passaram se voltar mais à comunicação rural, o que acarreta a divulgação de informações técnicas, políticas, econômicas e sociais que podem afetar a vida do homem do campo. Atualmente, os veículos de comunicação publicam diariamente notícias que despertam o interesse do público que vive na zona rural. Algumas cooperativas utilizam jornais, revistas e programas de rádio e televisão que são destinados exclusivamente aos agricultores, por conter informações que são diretamente importantes em suas atividades agrícolas cotidianas.

Tudo isso não deixa de ser parte de um processo que permite a compreensão da relação entre a comunicação e o jogo de poder da sociedade. Além disso, a sua evolução passou por diversas mudanças, que corresponderam aos interesses e necessidades de cada época histórica em que estiveram presentes e fizeram parte.

\section{Apontamentos metodológicos: a pesquisa empírica e suas escolhas}

Em termos metodológicos, essa pesquisa é um estudo de caso que tem como objetivo analisar o consumo das notícias através da mídia pelos agricultores que residem na zona rural do município de São Domingos, região oeste de Santa Catarina.

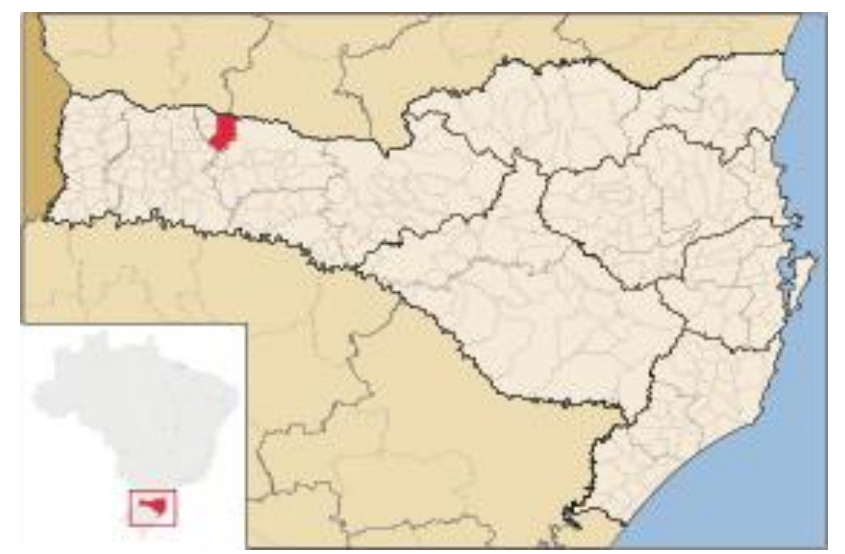

Figura 1 - Mapa do estado de Santa Catarina indicando a localização do município de São Domingos.

Buscamos entender a relação que existe entre os agricultores e a mídia, e de que forma as notícias que eles consomem interferem em suas atividades do dia a dia. Para isso, 
aplicamos questionários a um grupo de $18^{3}$ agricultores e, para o aprofundamento, realizamos entrevistas e observação participante com seis ${ }^{4}$ agricultores.

Yin (2001, p. 23) define o estudo de caso como uma "inquirição empírica", responsável por investigar fatos dentro do contexto da vida real, "quando a fronteira entre o fenômeno e o contexto não é claramente evidente e onde as múltiplas fontes de evidência são utilizadas". Além disso, Sifuentes (2008, p.29) acredita que algumas das características de um estudo de caso são: "retratar a realidade de forma complexa e profunda, enfatizar a interpretação em contexto e representar os diferentes e por vezes contraditórios pontos de vista em uma situação social”.

Tull (1976 apud BRESSAN, 2000) afirma que um estudo de caso é aquele que diz respeito a uma análise intensiva de uma situação particular e que a trata de forma intensa e profunda, com o mesmo objetivo da etnografia, de coletar detalhes reconhecidos apenas com longos períodos de pesquisa.

O primeiro passo utilizado para chegar aos resultados dessa pesquisa, foram os questionários, distribuídos entre 18 agricultores das seguintes comunidades de São Domingos: Linha Nova Arvorezinha, Imigra, Santo Antônio e São Brás. Através do resultado desses questionários, pudemos ter um conhecimento sobre a importância da mídia e das informações na vida do agricultor.

O segundo passo foi aprofundar a pesquisa de campo com os seis agricultores que se mostraram dispostos a prosseguir como informantes. Foram realizadas entrevistas em profundidade, todas em finais de semana, período em que os agricultores dispõem de mais tempo livre. As entrevistas possuíram um caráter etnográfico, pois, além dos questionamentos previstos em roteiro, foi realizado um acompanhamento da rotina dos agricultores entrevistados. As famílias, apesar de se mostrarem receosas no começo, demonstraram gostar de ter a oportunidade de relatar um pouco da sua vida e rotina.

\footnotetext{
${ }^{3}$ Os questionários aplicados tiveram como objetivo obter informações preliminares sobre os agricultores e sondar a disponibilidade dos mesmos para participar das entrevistas. Não se pretende apresentar uma visão que represente todos os agricultores de São Domingos-SC, embora seja possível captar elementos mais gerais dessa população, sendo essa uma das características do estudo de caso. Cabe, ainda, ressaltar que não há uma justificativa específica para o número de respondentes dos questionários ser 18 , apenas esse foi o número de agricultores, entre os procurados, que decidiram participar da pesquisa.

4 Aprofundamos a pesquisa com os seis agricultores que responderam, na fase de questionários, que teriam interesse em continuar em uma segunda etapa de investigação.
} 
A entrevista em profundidade permite que o pesquisador ajuste as perguntas de acordo com a ocasião e necessidade, bem como busque intensidade nas respostas. Ela é um recurso metodológico que busca, a partir das teorias do pesquisador, recolher respostas a partir da experiência subjetiva de uma fonte, que é selecionada a partir de conhecimentos que possa transmitir sobre o tema abordado (DUARTE, 2005).

\section{A mídia no cotidiano do receptor do meio rural}

A região oeste do estado de Santa Catarina é considerada o "celeiro" do estado, já que é responsável pela produção de grãos, aves e suínos, tendo, portanto, um papel importante no desenvolvimento econômico do estado. Além disso, é composta por frigoríficos de grande e médio porte, que estão ligados a produtores rurais em forma de integração.

São Domingos está localizada nessa região, a cerca de 600 quilômetros da capital do estado, Florianópolis. Com uma população de 9.491 habitantes (IBGE, 2011), caracteriza-se como um município essencialmente agrícola, sendo que $43,1 \%$ da sua população vive na zona rural. As famílias que moram nas comunidades rurais sobrevivem basicamente da agricultura, através do plantio de milho, soja, trigo, feijão, fumo, entre outros, além da suinocultura, avicultura e bovinocultura. Ocupa uma área de $413 \mathrm{~km}^{2}$, com densidade populacional de 35,5 habitantes por quilômetro. A população atual tem sua formação baseada nas etnias da colonização -italianos, alemães e luso-brasileiros.

As famílias entrevistadas possuem perfis diversos, variando o tamanho das propriedades e as atividades com as quais trabalham. O tamanho das propriedades varia de cinco a 40 hectares de terra. As entrevistas foram realizadas nas casas dos agricultores, durante finais de semana, muitas vezes enquanto eles estavam ocupados com suas atividades de costume, que normalmente não diminui de intensidade por se tratar de um sábado ou domingo.

Os dados obtidos através dos questionários serviram para conhecermos o consumo de mídia, especialmente de notícias, pelos moradores do meio rural. Foram aplicados 18 questionários, sendo três entrevistadas do sexo feminino e 15 do sexo masculino 5 . Entre eles,

\footnotetext{
5 A predominância de homens como respondentes dos questionários se deve ao fato de termos buscado os responsáveis pela propriedade. Ainda é visível a superioridade masculina na hierarquia do meio rural. Aqui,
} 
14 são casados, dois solteiros e dois separados. Quatorze têm filhos e quatro, não. Entre os agricultores que responderam o questionário, todos afirmaram que possuem acesso em casa à televisão e rádio onze têm acesso à internet, seis a jornal e quatro a revistas.

Quando se questiona por quais meios de comunicação os agricultores se mantêm informados, todos respondem televisão e rádio em primeiro lugar, e 11 ainda utilizam a internet, quatro, os jornais, e três, as revistas. Quando se fala em meio de comunicação que mais gosta e confia, ninguém cita jornal ou revista nessa lista. As preferências são pela televisão, que foi a resposta de 12 agricultores, quatro destacam o rádio e três, a internet. Os seis agricultores entrevistados consideram a internet como um meio de comunicação elitizado para as comunidades do interior, já que o custo normalmente é alto e os agricultores não estão dispostos a pagar, principalmente aqueles que não têm mais filhos em casa.

Os entrevistados consomem notícias diariamente, principalmente nos horários de trabalho, quando estão com o rádio ligado. Entre os seis agricultores entrevistados, o consumo da mídia pode ser considerado alto, já que todos ouvem o rádio enquanto trabalham, totalizando mais de quatro horas por dia. Entretanto, entendemos que eles estão tão acostumados com a presença das mídias, que não somam o tempo que gastam com elas enquanto fazem suas atividades, como quando responderam os questionários ${ }^{6}$.

A agricultura é o tema que mais os interessa nas notícias, segundo as respostas de 17 pessoas. Apenas um deles prefere notícias sobre política e economia. Oito deles acrescentam o esporte como uma de suas preferências, seguido de cinco que destacam a temática geral, dois que se interessam por economia, um por educação, um pelo tema mundo e um por notícias sobre política.

Os seis agricultores entrevistados e suas famílias acompanham diariamente notícias voltadas à agricultura, mas também dedicam tempo a assistir programas sobre outros temas, como notícias de esporte e programas de televisão voltados a artesanato e culinária, citados pelas mulheres, assim como as novelas, assistidas por homens e mulheres.

contudo, não nos deteremos na discussão de gênero, campo rico de investigação que não seria possível receber suficiente atenção neste trabalho.

${ }^{6}$ Alguns responderam no questionário que ocupam cerca de duas horas diárias para o consumo de mídia, enquanto na entrevista relataram que passam o dia ouvindo rádio na lavoura. 
Apesar de afirmarem que estão satisfeitos com a qualidade das notícias veiculadas sobre agricultura, eles comentam que algumas melhorias poderiam ser feitas no modo de produção das notícias.

As notícias são boas, mas tem muita coisa manipulada. A gente que trabalha e conhece a realidade da agricultura percebe que muitas coisas não são verídicas. Alguns grupos dominam e querem manipular as notícias, por isso a gente tem que filtrar o que consome (Benjamin).

Muita coisa que a gente assiste na TV sabemos que não são verdadeiras. Mas tem gente que assiste e que não entende nada da agricultura que pensa que é tudo uma maravilha, que os agricultores nadam no dinheiro e que reclamam de barriga cheia, mas a realidade não é essa. (Wanderlei)

Percebemos que os agricultores ouvidos estão preocupados com a qualidade das informações e notícias que recebem, porque isso interfere de forma direta nas atividades que realizam em suas propriedades. Mesmo que a realidade da produção de notícias possa parecer distante, eles opinam sobre esse universo, o que pode ser relacionado com a proximidade que eles têm com os meios em seu dia a dia, e também por serem conhecedores dessa tema.

Duas questões respondidas pelos agricultores demonstraram claramente a importância da mídia na realização de suas tarefas rotineiras. Quatorze questionados responderam que os meios de comunicação aos quais têm acesso interferem, um pouco ou muito, em seu cotidiano. Os demais (quatro) consideram que não interferem em nada. Da mesma forma, todos os agricultores responderam que as notícias ajudam nas atividades agrícolas, sendo que oito afirmam que a mídia ajuda muito. Os entrevistados relatam que utilizam as notícias que consomem de alguma forma em seu cotidiano e nas atividades que exercem em suas propriedades.

Esses dias eu estava assistindo uma notícia no Globo Rural que ensinava como fazer as fontes de água protegidas. E depois eu fiz isso na nossa fonte. (Márcio)

Têm notícias que a gente ocupa na propriedade. Eu vi na televisão a importância da agricultura de precisão e, baseado nesses dados eu fiz uma parte da lavoura assim. (Benjamin)

Entretanto, os agricultores entrevistados têm dificuldades de destacar notícias que tenham lhes chamado a atenção, mesmo valorizando as informações que a mídia divulga. Podemos entender isso como resultado do grande volume de notícias divulgadas pela mídia, sendo difícil memorizar alguma em especial. 
Eles comentam que todas as informações são importantes e que são utilizadas na propriedade na medida do possível, de acordo com a realidade de cada família. Todos os agricultores entrevistados concordam que as notícias de agricultura são importantes e têm um papel relevante em suas atividades rotineiras. Conforme os informantes, as notícias trazem informações que são utilizadas durante o dia a dia em cada propriedade e permitem que o agricultor fique por dentro do que está acontecendo no mercado local, nacional e internacional.

Eu gosto de acompanhar as notícias da agricultura, porque a gente fica sabendo do mercado e fica atualizado. A gente não pode ficar pra trás, tem que se manter informado sempre (Márcio).

As notícias ajudam muito, inclusive na parte de comercialização, de poder ficar atento às perspectivas do mercado. Isso ajuda na hora de comercializar os produtos (Benjamin).

As notícias são bem importantes pra nós, da agricultura. A gente aprende muito com elas e as informações podem ser utilizadas na nossa propriedade. A gente também vai aprendendo com as notícias que mostram como as outras pessoas fazem algumas atividades e tentamos fazer igual ou melhorar cada ideia para aplicar em casa (Aldemir).

\subsection{Rádio e televisão: os preferidos}

Todos os agricultores entrevistados possuem televisão e rádio, muitas vezes com mais de um aparelho em casa, como é o caso de Márcio, que possui três aparelhos de rádio. Enquanto realiza algumas de suas atividades na agricultura, está com o rádio ligado, sempre na emissora local, a Rádio Clube ${ }^{7}$, como forma de ficar informado sobre as notícias que acontecem na cidade, já que não tem acesso ao jornal. Como Márcio trabalha com suinocultura, possui um aparelho de rádio instalado no chiqueiro, pois "deixa os animais mais tranquilos e evita infarto nos porcos”. Além disso, em época que está trabalhando com a lavoura de fumo, possui um aparelho móvel, que sempre lhe acompanha.

Com o rádio a gente fica sabendo até as horas enquanto está trabalhando, já que o uso de relógio é complicado em atividades da agricultura. (Márcio)

\footnotetext{
${ }^{7}$ A cidade de São Domingos possui dois meios de comunicação local: a Rádio Clube, AM 1190, e o Jornal do Povo, veiculado semanalmente. O município não possui emissoras de TV, sendo que a mais próxima está localizada na cidade de Xanxerê, que fica a cerca de 45 quilômetros de distância.
} 
Outro local onde há a presença do aparelho de rádio é na cozinha. Enquanto as mulheres dos entrevistados realizam suas atividades domésticas, estão com o aparelho ligado, como forma de entretenimento e de se manter informadas também. A preferência delas também é pela emissora local, que possui um programa informativo até as $10 \mathrm{~h}$, seguido de programa de entretenimento, com destaque a pautas locais e músicas.

Outro entrevistado que destaca o gosto pelo rádio é Wanderley, que acompanha a emissora local diariamente. Um de seus programas preferidos vai ao ar ao meio-dia e o mantém informado sobre o mercado agrícola e os preços dos produtos, como milho e soja. É nesse horário que a família está toda reunida, para o almoço. Depois, cada um segue em suas atividades.

Aldemir também é muito adepto do rádio, considerado seu meio de comunicação preferido. A esposa concorda e menciona que já foi até "trocada" pelo aparelho algumas vezes. Enquanto trabalha, Aldemir está sempre com o rádio ligado, intercalando entre programas de notícias ou músicas. Não dispensa o aparelho durante o almoço também.

Com o rádio ligado o tempo passa mais rápido. (Aldemir)

José gosta de ouvir rádio enquanto trabalha e quando está em casa também. O agricultor possui o aparelho ligado sempre que pode, inclusive nas épocas de plantio e colheita na lavoura. Os maquinários em que trabalha, como trator e colheitadeira, são modernos e possuem cabine, tendo o rádio instalado neles. Dessa forma, o agricultor está sempre em contato com o veículo de comunicação, normalmente sintonizado na emissora local.

Já Benjamim dedica seu tempo livre ao consumo de programas de televisão, normalmente no período da noite, que é o horário em que está descansando. Também utiliza a internet, para procurar notícias específicas dos temas que mais lhe interessam e dos fatos que estão acontecendo no momento. Benjamim e Márcio são os únicos entrevistados que têm acesso a internet, mesmo que o segundo não tenha um contato tão intenso, porque ainda está se adaptando à tecnologia. Vale ressaltar que Benjamim é o único entrevistado que possui outra atividade, que não está ligada à agricultura, sua ocupação como servidor público.

Eldo também prefere a televisão, à qual dedica a maior parte do seu tempo de consumo. $\mathrm{O}$ agricultor, exceto em épocas de plantio e colheita, está dentro de casa a partir das 
17h. Desse horário em diante, dedica seu tempo ao consumo de notícias pela televisão, sendo sua preferência o Canal Rural, voltado exclusivamente às notícias da agricultura. Eldo dorme cedo, por volta das $21 \mathrm{~h}$. Contudo, às $5 \mathrm{~h}$ já está acordado, na cozinha, tomando seu chimarrão e assistindo televisão ou ouvindo as primeiras notícias do rádio.

\section{Considerações}

Com o passar dos anos, o perfil das famílias que residem no campo foi alterado, devido à chegada de novas tecnologias e o maior acesso a informação e educação. Contudo, alguns valores permanecem inalterados pelas famílias camponesas e isso pôde ser conferido durante as entrevistas realizadas. Esses valores podem ser encontrados através da forte presença da religião nas famílias, com participação ativa em celebrações da comunidade.

No campo, até há algum tempo, o acesso às notícias se dava por meio de emissoras de rádio local, muitas vezes partidarizadas e com conteúdo jornalístico pouco desenvolvido. As notícias recebidas pela televisão eram transmitidas por meio da antena parabólica, que não transmite informações sobre a realidade local.

Contudo, atualmente, essa realidade mudou, através das facilidades tecnológicas que estão ao alcance de boa parte da população, inclusive a que vive no meio rural. A chegada de algumas tecnologias ao meio rural também foram responsáveis por alterar o perfil das famílias agricultoras. Entre essas facilidades que estão ao alcance dos agricultores, pode-se destacar a chegada do celular, de emissoras de TV local, de canais por assinatura, bem como do computador e da internet, que também já estão presentes em algumas propriedades rurais de São Domingos, como pudemos perceber na pesquisa.

Nem todos os agricultores entrevistados têm acesso a internet. Os que têm, deve-se, principalmente, à situação financeira e à infraestrutura da propriedade e da localidade, que possibilitam o acesso. $\mathrm{O}$ fato de terem filhos em idade escolar também motiva os agricultores a ter a tecnologia em casa. Os outros entrevistados, que não possuem internet em casa, mesmo tendo filhos em fase escolar, também gostariam desse acesso. Mas por estarem localizados longe dos fios que transmitem o sinal, esse acesso se torna inviável financeiramente.

Com o objetivo de compreender a importância que a mídia tem na vida dos agricultores e entender de que forma as notícias que consomem interferem em suas tarefas, o 
estudo pôde demonstrar que os agricultores entrevistados fazem um uso expressivo dos veículos de comunicação, possuindo, até mesmo, uma relação afetiva e, em certa parte, de dependência com os mesmos.

As famílias agricultoras mantém o costume de estarem reunidas, principalmente à noite, ao redor da televisão, que ganha destaque nas salas de estar. E esse é o tempo que elas dedicam a conversar sobre como foi o dia de cada membro e aproveitar para descansar. O papel da televisão para os agricultores entrevistados é o de socialização, pois o momento em que se reúnem em torno do aparelho serve como momento de reunião. Dificilmente há uma atenção exclusiva ao veículo. Enquanto os homens e os filhos assistem televisão, a mulher normalmente está envolvida preparando a janta ou realizando algum tipo de artesanato, como o crochê. Também é um momento de auxiliar os filhos nas atividades escolares. É comum, ainda, que se discuta e comente sobre alguma notícia que chama atenção. Além de noticiários, destacam-se as novelas, entre homens, mulheres e filhos.

Por meio dos questionários pudemos perceber que os agricultores têm acesso aos meios de comunicação como televisão, rádio, internet, jornal e revista e consomem as notícias neles produzidos, principalmente as que envolvem o tema agricultura. Além disso, eles comentam que as notícias que falam sobre o meio rural são utilizadas em suas atividades rotineiras. É a partir daí que eles se mantêm informados sobre novas tecnologias, produtos, previsão do tempo e outras informações voltadas à área.

Os agricultores não têm muito costume de ler revista ou jornal, exceto os distribuídos pelas cooperativas. Contudo, estão sempre em busca de informações que possam deixá-los cientes de tudo o que está acontecendo no mundo, principalmente com notícias de novas tecnologias e previsão do tempo.

Para compreender de que forma se dá o consumo da mídia pelos agricultores, foi preciso aprofundar o conhecimento da realidade da zona rural, bem como as dificuldades enfrentadas por eles e os benefícios de viver no campo. Embora já existisse essa convivência e conhecimento, aprofundamos a observação, fazendo com a pesquisa pudesse reconhecer outros fatores entre a relação dos agricultores e a mídia.

Dessa forma, conclui-se que os agricultores têm grande interesse pelos veículos de comunicação e pelas informações neles divulgadas. O rádio e a televisão são os meios que mais estão presentes na rotina dos agricultores e de suas famílias, dedicando mais de duas 
horas por dia ao consumo de mídias, além das tantas horas em que o rádio é companhia e eles não percebem estarem fazendo consumo da mídia. As notícias de agricultura, as mais procuradas por eles, têm, ainda, papel importante no conhecimento sobre a área em que trabalham, influenciando em sua atividade de sustento ${ }^{8}$.

Assim, chegamos à conclusão de que os meios de comunicação estão presentes em suas rotinas de forma bem mais intensa do que imaginávamos. Além de exercer o papel de informar, os meios de comunicação, principalmente os que são de acesso mais fácil (rádio e televisão), atuam como companheiros dos agricultores.

\section{Referências}

BORDENAVE, Juan E. Diaz. Além dos meios e mensagens: introdução a comunicação como processo, tecnologia, sistema e ciência. Editora Vozes, 2003.

BRESSAN, Flávio. O método do estudo de caso. Administração online, v. 1, n 1, 2000. Disponível em

<http://www2.uel.br/pessoal/amanthea/ctu/arquivos/monografias/estudo_de_caso.htm> Acesso em: 31 mar. 2012.

DUARTE, Jorge. Entrevista em profundidade. In: DUARTE, Jorge; BARROS, Antonio (Org.). Métodos e Técnicas de Pesquisa em Comunicação. São Paulo: Editora Atlas, 2005.

GOBBI, Suzane Paula. Jornal Nacional e violência contra a mulher: como as notícias contribuem na formação de opinião dos jovens. Monografia (Graduação em Comunicação Social - Jornalismo). Universidade Comunitária da Região de Chapecó, Chapecó-SC, 2011.

GOMES, Itania Maria Mota. Efeito e recepção: a interpretação do processo receptivo em duas tradições de investigação sobre os media. Rio de Janeiro: E-papers Serviços Editoriais, 2004.

GROHMANN, Rafael do Nascimento. Os estudos de recepção nos últimos 30 anos: revisão e perspectivas. In: XIV Congresso de Ciências da Comunicação na Região Sudeste, Rio de Janeiro, 2009.

IBGE. Censo Demográfico 2010. Rio de Janeiro: IBGE, 2011.

\footnotetext{
${ }^{8}$ No entanto, não podemos afirmar que há uma influência nos rendimentos financeiros da atividade a partir desses conhecimentos. A interferência da mídia na atividade de sustento se dá pelos conhecimentos agregados e, mais ainda, pela presença constante dos meios, especialmente do rádio, durante o trabalho dos agricultores.
} 
JACKS, Nilda; RONSINI, Veneza Mayora. Mediações na recepção: estudo comparativo entre receptor urbano e rural. In: BRAGA, Jose Luiz; NETO, Antonio Fausto; PORTO, Sergio Dayrell (Orgs.). A encenação dos sentidos: mídia, cultura e política. Rio de Janeiro: Diadorim, 1996.

JACKS, Nilda; ESCOSTEGUY, Ana Carolina. Comunicação e recepção. São Paulo: Hacker Editores, 2005.

LEFEBVRE, Henri. De lo rural a lo urbano. 3 ed. Barcelona: Península, 1975.

PÉREZ, Edelmira. Hacia una nueva visión de lo rural. In.: GIARRACCA, Norma (Org.). ¿Una nueva ruralidad en América Latina? Buenos Aires: CLACSO, 2001.

POZENATO, Kenia Maria Menegotto; GIRON, Loraine Slomp. Colônia e Comunicação: A influência dos meios de comunicação na zona rural. In: IX Seminário Internacional da Comunicação. Porto Alegre: Edipucrs, 2007.

SIFUENTES, Lírian. Juventude camponesa e televisão: um estudo sobre as representações do campo e da cidade. Monografia (Graduação em Comunicação Social - Habilitação em Jornalismo). Universidade Federal de Santa Maria, Santa Maria-RS, 2008.

- Perspectivas de estudo da audiência midiática: aproximações e distanciamentos. In: XI Congreso Latinoamericano de Investigadores de la Comunicación. Montevidéu: Alaic, 2012.

SIQUEIRA, Deis; OSÓRIO, Rafael. O conceito de rural. In.: GIARRACCA, Norma (Org.). ¿Una nueva ruralidad en América Latina? Buenos Aires: CLACSO, 2001.

SOBARZO, Oscar. O urbano e o rural em Henri Lefebvre. In: SPOSITO, M. Encarnação Beltrão e WHITACKER, Arthur Magon (Org.). Cidade e Campo: relações e contradições entre urbano e rural. São Paulo: Expressão Popular, p. 53-64, 2006.

TEUBAL, Miguel. Globalización y nueva ruralidad en America Latina. In: GIARRACA, Norma (Org.) ¿Una nueva ruralidad en América Latina? Buenos Aires: CLACSO, 2001.

VEIGA, José Elias da. Cidades Imaginárias: O Brasil é menos Urbano do que calcula. Editora Autores Associados. Campinas, 2003.

WANDERLEY, Maria de Nazareth Baudel. A ruralidade no Brasil moderno. Por um pacto social pelo desenvolvimento rural. In: GIARRACCA, Norma (Org.). ¿Una nueva ruralidad en América Latina? Buenos Aires: CLACSO, 2001.

WILliAMS, Raymond. O Campo e a Cidade: na História e na Literatura. São Paulo: Companhia das Letras, 1989.

YIN, Robert K. Estudo de caso: planejamento e métodos. Porto Alegre: Bookman, 2001. 
Original recebido em: 30/10/2012

Aceito para publicação em: 03/12/2012

Resumo sobre o autor

Lirian Sifuentes é Professora do curso de Jornalismo da Unochapecó. Doutoranda em Comunicação pela PUCRS. Mestre em Comunicação e jornalista pela UFSM.

Keli Camiloti é Jornalista graduada pela Unochapecó. 